University of Wollongong

Research Online

Australian Institute for Innovative Materials -

Papers

Australian Institute for Innovative Materials

2012

Synthesis and electrochemical characterization of LiFeP04/C-polypyrrole composite prepared by a simple chemical vapor deposition method

Qiang Gong

Shanghai Jiaotong University

Yu-Shi He

Shanghai Jiaotong University

Yang Yang

University of Wollongong, yy922@uow.edu.au

Xiao Zhen Liao

Shanghai Jiaotong University

Zi-Feng Ma

Shanghai Jiaotong University

Follow this and additional works at: https://ro.uow.edu.au/aiimpapers

Part of the Engineering Commons, and the Physical Sciences and Mathematics Commons

Research Online is the open access institutional repository for the University of Wollongong. For further information contact the UOW Library: research-pubs@uow.edu.au 


\title{
Synthesis and electrochemical characterization of LiFePO4/C-polypyrrole composite prepared by a simple chemical vapor deposition method
}

\author{
Abstract \\ A LiFePO4/C-polypyrrole ( $\mathrm{LiFePO}_{4} / \mathrm{C}-\mathrm{PPy}$ ) composite as a high-performance cathode material is \\ successfully prepared through a simple chemical vapor deposition (CVD) method. According to the \\ transmission electron microscope (TEM) analysis, the surface of the $\mathrm{LiFePO}_{4} / \mathrm{C}$ is surrounded with PPy in \\ the $\mathrm{LiFePO}_{4} / \mathrm{C}$-PPy composite. The as-prepared $\mathrm{LiFePO}_{4} / \mathrm{C}$-PPy material shows outstanding rate \\ capability at $20^{\circ} \mathrm{C}$ and good cycle performance at $55^{\circ} \mathrm{C}$ in comparison with those of the bare $\mathrm{LiFePO} / \mathrm{C}$ \\ material against $\mathrm{Li}$ anode. After 700 cycles, the discharge capacity of $\mathrm{LiFePO} 4 / \mathrm{C}-\mathrm{PPy}$ could still remain \\ $110 \mathrm{~mA} \mathrm{~h} \mathrm{~g}^{-1}$ with the retention of $82 \%$ at $5 \mathrm{C}$ rate at $55^{\circ} \mathrm{C}$. This could be ascribed to the fact that PPy \\ coating on $\mathrm{LiFePO}_{4} / \mathrm{C}$ could significantly improve the ionic conductivity of the LiFePO $4 / \mathrm{C}-\mathrm{PPy}$ composite \\ and could greatly reduce the electrode resistance. Furthermore, the PPy coating on $\mathrm{LiFePO} 4 / \mathrm{C}$ could \\ effectively decrease the dissolution of $\mathrm{Fe}$ in the $\mathrm{LiPF}_{6}$ electrolyte and subsequently suppress the \\ reduction of Fe ions on anode.

\section{Keywords} \\ deposition, composite, polypyrrole, c, lifepo4, characterization, electrochemical, synthesis, vapor, \\ chemical, simple, method, prepared

\section{Disciplines \\ Engineering | Physical Sciences and Mathematics}

\section{Publication Details} \\ Gong, Q, He, Y, Yang, Y, Liao, X.\& Ma, Z (2012), Synthesis and electrochemical characterization of \\ LiFeP04/C-polypyrrole composite prepared by a simple chemical vapor deposition method, Journal of \\ Solid State Electrochemistry, 16(4), pp. 1383-1388.
}




\title{
Synthesis and electrochemical characterization of $\mathrm{LiFePO}_{4} / \mathrm{C}$-polypyrrole
}

\section{composite prepared by a simple chemical vapor deposition method}

\author{
Qiang Gong ${ }^{\mathrm{a}}$, Yu-Shi He ${ }^{\mathrm{a}}$, Yang Yang ${ }^{\mathrm{a}, \mathrm{b}}$, Xiao-Zhen Liao ${ }^{\mathrm{a}}$, Zi-Feng Ma ${ }^{* a}$ \\ ${ }^{a}$ Department of Chemical Engineering, Shanghai Jiao Tong University, Shanghai 200240, P.R. \\ China. \\ ${ }^{b}$ ARC Centre of Excellence for Electromaterials Science, Intelligent Polymer Research Institute, \\ University of Wollongong ,NSW 2519, Australia
}

\begin{abstract}
A $\mathrm{LiFePO}_{4} / \mathrm{C}$-polypyrrole $\left(\mathrm{LiFePO}_{4} / \mathrm{C}\right.$-PPy) composite as a high performance cathode material is successfully prepared through a simple chemical vapor deposition (CVD) method. According to the transmission electron microscope (TEM) analysis the surface of the $\mathrm{LiFePO}_{4} / \mathrm{C}$ is surrounded with $\mathrm{PPy}$ in the $\mathrm{LiFePO}_{4} / \mathrm{C}$-PPy composite. The as-prepared $\mathrm{LiFePO}_{4} / \mathrm{C}$-PPy material shows outstanding rate capability at $20{ }^{\circ} \mathrm{C}$ and good cycle performance at $55{ }^{\circ} \mathrm{C}$ in comparison with those of the bare $\mathrm{LiFePO}_{4} / \mathrm{C}$ material against $\mathrm{Li}$ anode. After 700 cycles, the discharge capacity of $\mathrm{LiFePO}_{4} / \mathrm{C}$-PPy could still remain $110 \mathrm{mAh} \mathrm{g}^{-1}$ with the retention of $82 \%$ at $5 \mathrm{C}$ rate at $55{ }^{\circ} \mathrm{C}$. It could be ascribe to the reasons that PPy coating on $\mathrm{LiFePO}_{4} / \mathrm{C}$ could significantly improve the ionic conductivity of the $\mathrm{LiFePO}_{4} / \mathrm{C}$-PPy composite and greatly reduce the electrode resistance. Furthermore, the PPy coating on $\mathrm{LiFePO}_{4} / \mathrm{C}$ could effectively decrease the dissolution of $\mathrm{Fe}$ in the $\mathrm{LiPF}_{6}$ electrolyte and subsequently suppress the reduction of $\mathrm{Fe}$ ions on anode.
\end{abstract}

\footnotetext{
* Corresponding author. Tel: (+86) 21 54742894. Fax: +86-21-54747717. Email: zfma@sjtu.edu.cn
} 
Keywords: $\mathrm{LiFePO}_{4}$; Polypyrrole; Chemical vapor deposition; Cathode; Lithium batteries

\section{Introduction}

As a rare metal-free material, $\mathrm{LiFePO}_{4}$ has been considered to be a promising cathode material for the next generation of rechargeable lithium ion batteries due to its reasonable theoretical capacity (170 $\left.\mathrm{mAh}^{-1}\right)$, environmentally benign, low cost, and high safety [1]. However, the main problem of $\mathrm{LiFePO}_{4}$ is its poor lithium-ion diffusion rate and low electronic conductivity. Tremendous efforts have been made over the past few years to overcome these drawbacks, such as carbon coating [2-4], metal doping [5, 6] and particle size nanonization [7, 8]. Nevertheless, the cycling performance of $\mathrm{LiFePO}_{4}$ at elevated temperature and its high rate performance are still unable to satisfy the requirements for practical application in electric vehicles.

In recent years, conducting polymers, such as PPy, polyaniline (PANI), and poly (3, 4ethylenedioxythiophene) (PEDOT), have been attracting much attention as additives or coating materials for lithium ion batteries. Investigations on $\mathrm{V}_{2} \mathrm{O}_{5} / \mathrm{PPy}$ [9], $\mathrm{LiMn}_{2} \mathrm{O}_{4} / \mathrm{PPy}$ [10], $\mathrm{LiFePO}_{4} / \mathrm{PEDOT}$ [11], $\mathrm{LiFePO}_{4} / \mathrm{PANI}$ [12], and $\mathrm{LiFePO}_{4} / \mathrm{PPy}$ [12-19] have been reported. Pasquier et al. [10] have coated $\mathrm{LiMn}_{2} \mathrm{O}_{4}$ particles with PPy to improve the cyclability of $\mathrm{LiMn}_{2} \mathrm{O}_{4}$ cathode at elevated temperature by suppressing the dissolution of $\mathrm{Mn}$ in the $\mathrm{LiPF}_{6}$ electrolyte. Goodenough et al. [12-15] first presented a concept of substituting the inactive C and PTFE binder of the $\mathrm{LiFePO}_{4}$ cathode with a conducting polymer like PPy or PANI. The synthesized $\mathrm{LiFePO}_{4} / \mathrm{C}-\mathrm{PPy}$ and $\mathrm{LiFePO}_{4} / \mathrm{C}$-PANI cathodes exhibited excellent rate capability. But they didn't report the electrochemical performance of these materials at high temperatures.

Vapor phase polymerization (VPP) was first described by Mohamadi et al. [20] as a CVD process using $\mathrm{FeCl}_{3}$ as oxidants for polymerization of polypyrrole films. Then using $\mathrm{Fe}(\mathrm{III})$ 
tosylate as the oxidant has been reported an excellent route to form both smooth and highly conducting films [21]. When electrode materials are coated by PPy in this vapor phase process, the pyrrole gas could penetrate and coat in the inner pore area of the powder. This would reduce the activity of cathode/anode surface and further decrease undesirable reactions with the electrolyte, while the lithium intercalation would not be inhibited. This strategy to synthesize the PPy films grown on the surface of $\mathrm{LiFePO}_{4}$ with CVD procedure would be helpful for the further development of electrode material for lithium ion batteries.

In this paper, the effect of PPy coating on the rate capability of $\mathrm{LiFePO}_{4} / \mathrm{C}$ material is firstly investigated at low temperature $\left(-20^{\circ} \mathrm{C}\right)$. It is also demonstrated that the high-temperature cycle performance of $\mathrm{LiFePO}_{4} / \mathrm{C}$ material can be greatly enhanced with the coating of PPy by using the simple CVD method whether the counter electrode is metallic lithium or mesocarbon microbead (MCMB).

\section{Experimental}

$\mathrm{LiFePO}_{4} / \mathrm{C}$ powder with carbon content of $2.4 \mathrm{wt} \%$ was synthesized according to Ref. [22]. $\mathrm{LiFePO}_{4} / \mathrm{C}$-PPy composite was prepared by chemical vapor deposition method using $\mathrm{Fe}(\mathrm{III})$ tosylate as oxidant: $5 \mathrm{~g} \mathrm{LiFePO}_{4} / \mathrm{C}$ powder was dispersed in $23.5 \mathrm{~g}$ ethanol solution containing $25 \mathrm{wt} \% \mathrm{Fe}(\mathrm{III})$ tosylate (Sigma-Aldrich). The solution was magnetically stirred for $15 \mathrm{~min}$ and heated into slurry at $60{ }^{\circ} \mathrm{C}$. Then the slurry was exposed to pyrrole monomer vapor directly over the liquid pyrrole monomer (98\%, Sigma-Aldrich, distilled prior to usage) on a filter paper in a sealed container at $60{ }^{\circ} \mathrm{C}$ for $1 \mathrm{~h}$. The final $\mathrm{LiFePO}_{4} / \mathrm{C}$-PPy product was washed with ethanol, and dried at $60{ }^{\circ} \mathrm{C}$ in a vacuum oven for $2 \mathrm{~h}$.

The PPy content in the composite was analyzed by thermogravitric analysis (NETZSCH TG 209 F1) operated under flowing Ar. The temperature was scanned from 30 to $800{ }^{\circ} \mathrm{C}$ at a rate of $10{ }^{\circ} \mathrm{C}$ min $^{-1}$ using an $\mathrm{Al}_{2} \mathrm{O}_{3}$ crucible. The particle images of the samples were observed using 
transmission electron microscopy (TEM, JEM-2010/INCA OXFORD). The cross-section morphology of electrodes after cycling was observed using a scanning electron microscope (FESEM, SIRION 200, FEI) at an accelerating voltage of $5 \mathrm{kV}$. Energy dispersive X-ray spectroscopy (EDX, INCA, OXFORD) was used to analyze the compositions of electrodes.

Sample electrodes were prepared by slurrying the sample powder with 10 wt\% poly(vinylidene fluoride) (PVDF) and 15 wt\% Super-P carbon black (Timcal) in N-methyl-2pyrrolidinone (NMP) solvent, and then casting the mixture onto an aluminum foil. After vacuum drying at $120^{\circ} \mathrm{C}$ for $8 \mathrm{~h}$, the electrode disks were punched and weighed. The cathodes were incorporated into cells with a lithium foil counter electrode (so-called half-cell configuration), a Celgard $^{@}$-2700 separator, a $1 \mathrm{M} \mathrm{LiPF}_{6}$ / ethylene carbonate (EC) + dimethyl carbonate (DMC) + diethyl carbonate (DEC) + ethylmethyl carbonate (EMC) (1:1:1:3, v/v) electrolyte for low temperature $\left(-20{ }^{\circ} \mathrm{C}\right)$ and a $1 \mathrm{M} \mathrm{LiPF}_{6} / \mathrm{DMC}+\mathrm{EC}(1: 1)$ electrolyte for room temperature $\left(20{ }^{\circ} \mathrm{C}\right)$ and high temperature $\left(55^{\circ} \mathrm{C}\right)$ test. The active material loaded on the electrode disks was about $4.5 \mathrm{mg} / \mathrm{cm}^{2}$. Galvanostatic charge-discharge cycling tests for the cells were performed within a range of 2.0-4.2 V using a battery test system (LAND CT2001A model, Wuhan Jinnuo Electronics Co., Ltd). Parallel tests were made for charge-discharge measurements. The specific capacities of the samples were calculated based on the mass of the composites. Furthermore, the negative electrode in the full-cell test was made of 94\% MCMB graphite and 6\% PVDF on $\mathrm{Cu}$ foil. And the charge/discharge tests of the entire cells were performed at $1 \mathrm{C}\left(1 \mathrm{C}=160 \mathrm{~mA} \mathrm{~g}^{-1}\right)$ rate between 2.5 and $3.8 \mathrm{~V}$ on the same battery test system at $55{ }^{\circ} \mathrm{C}$. Iron dissolution from the sample powders upon storage in the electrolyte was analyzed by an ICAP6300 inductively coupled plasma optical emission spectrometer (ICP-OES) (Thermal, USA). For iron dissolution test, $1 \mathrm{~g}$ sample powder was stored in a closed bottle containing $10 \mathrm{ml}$ of electrolyte solution under Ar atmosphere. The bottle was sealed in an aluminum soft package to confirm the 
completely sealed condition during the long term test. The solution was removed after 25 days storage at $55{ }^{\circ} \mathrm{C}$ and was analyzed.

Electrochemical impedance measurements of the cells were carried out using a SI1260 Impedance/gain-phase analyzer in conjunction with the SI1287 electrochemical interface. The amplitude of the alternating current signal was $5 \mathrm{mV}$ over the frequency range between $100 \mathrm{kHz}$ and $1 \mathrm{mHz}$.

\section{Results and discussion}

Fig. 1 indicates TEM images of $\mathrm{LiFePO}_{4} / \mathrm{C}$ and $\mathrm{LiFePO}_{4} / \mathrm{C}$-PPy. The surface of $\mathrm{LiFePO}_{4} / \mathrm{C}$ particles is very smooth in Fig. 1a. It could be found from Fig. 1b that there is a large amount of PPy wrapping and connecting the $\mathrm{LiFePO}_{4}$ particles. And the distinct PPy film could be observed on the surface of $\mathrm{LiFePO}_{4}$ particles in Fig. 1c. Thereby it could ensure good electrical continuity between $\mathrm{LiFePO}_{4}$ particles. The result obtained by TG analysis indicates that the amount of PPy in the $\mathrm{LiFePO}_{4} / \mathrm{C}-\mathrm{PPy}$ composite was about $11.1 \mathrm{wt} \%$.

The rate capabilities of the prepared $\mathrm{LiFePO}_{4} / \mathrm{C}$ and $\mathrm{LiFePO}_{4} / \mathrm{C}$-PPy were evaluated and compared at $20{ }^{\circ} \mathrm{C}$ and $-20{ }^{\circ} \mathrm{C}$, respectively, as shown in Fig. 2. The cells were charged using the same current density as the following discharge test before each rate capability test. In Fig. 2a, it could be seen that the as-prepared $\mathrm{LiFePO}_{4} / \mathrm{C}-\mathrm{PPy}$ composite shows a superior rate capability over $2 \mathrm{C}\left(320 \mathrm{~mA} \mathrm{~g}^{-1}\right)$ rate and the overpotential at high discharge rates is significantly reduced in comparison with the pristine $\mathrm{LiFePO}_{4} / \mathrm{C}$ at $20{ }^{\circ} \mathrm{C}$. The discharge capacity of $\mathrm{LiFePO}_{4} / \mathrm{C}-\mathrm{PPy}$ composite could still remain about $80 \mathrm{mAh} \mathrm{g}^{-1}$ at $20 \mathrm{C}$ rate. Research on low temperature performance of $\mathrm{LiFePO}_{4} / \mathrm{C}$ material is still a challenging requirement. Herein, Fig. 2b compares the rate capabilities of the $\mathrm{LiFePO}_{4} / \mathrm{C}$ and $\mathrm{LiFePO}_{4} / \mathrm{C}$-PPy at $-20{ }^{\circ} \mathrm{C}$. It could be found that the $\mathrm{LiFePO}_{4} / \mathrm{C}$-PPy composite doesn’t show an outstanding advantage over $\mathrm{LiFePO}_{4} / \mathrm{C}$ material, which could be primarily attributed to the poor electronic conductivity of PPy at low temperature. 
So PPy coating could not noticeably improve the rate capability of $\mathrm{LiFePO}_{4} / \mathrm{C}$ material at low temperature.

As is well known, the poor high-temperature cycling performance of $\mathrm{LiFePO}_{4} / \mathrm{C}$ is a major drawback at high rates. Therefore the effect of PPy coating on the cycling stability of $\mathrm{LiFePO}_{4} / \mathrm{C}$ material at $5 \mathrm{C}$ charge/discharge rate at $55{ }^{\circ} \mathrm{C}$ is shown in Fig. 3 against $\mathrm{Li}$ anode. As shown in Fig. 3a, the $\mathrm{LiFePO}_{4} / \mathrm{C}$-PPy cathode exhibited excellent high-temperature cycling stability with a first discharge capacity of $135 \mathrm{mAh} \mathrm{g}^{-1}$. The steady discharge capacities could be still achieved at $110 \mathrm{mAh} \mathrm{g}^{-1}$ after 700 cycles and the capacity retention was about $82 \%$. The initial discharge capacity of the bare $\mathrm{LiFePO}_{4} / \mathrm{C}$ electrode is $149.7 \mathrm{mAh} \mathrm{g}^{-1}$. However, the retention value of discharge capacity is only about $40 \%$ after 300 cycles. Fig. 3b exhibits the discharge profiles of the prepared samples at different cycle numbers. It is clear that the $\mathrm{LiFePO}_{4} / \mathrm{C}$-PPy cathode displays a relatively stable discharge voltage plateau between about 3.4 and $3.5 \mathrm{~V}$ vs. $\mathrm{Li}^{+} / \mathrm{Li}$ during 700 cycles. Nevertheless, the discharge plateau of pristine $\mathrm{LiFePO}_{4} / \mathrm{C}$ is only around 2.6 $\mathrm{V}$ at first cycle and drops to around $2.0 \mathrm{~V}$ at $300^{\text {th }}$ cycle.

AC electrochemical impedance spectra are taken to understand the effects of PPy coating on the high-rate cycling performance of $\mathrm{LiFePO}_{4} / \mathrm{C}$ electrode at elevated temperature, the AC impedance spectra of $\mathrm{Li} \mid \mathrm{LiFePO}_{4} / \mathrm{C}-\mathrm{PPy}$ and $\mathrm{Li} \mid \mathrm{LiFePO}_{4} / \mathrm{C}$ cells were tested after $50^{\text {th }}$ cycle and $200^{\text {th }}$ cycle. As shown in Fig. 4, the total interfacial resistance of the $\mathrm{Li} \mid \mathrm{LiFePO}_{4} / \mathrm{C}$ cell, reflected by the high frequency semicircle, was much larger than that of $\mathrm{Li} \mid \mathrm{LiFePO}_{4} / \mathrm{C}-\mathrm{PPy}$ cell. Furthermore, the total interfacial resistance of the $\mathrm{Li} \mid \mathrm{LiFePO}_{4} / \mathrm{C}$ cell increased obviously after 200 cycles to 3 times of that after 50 cycles. Whereas the total interfacial resistance of $\mathrm{Li} \mid \mathrm{LiFePO} / \mathrm{C}$-PPy cell did not change much after 200 cycles. There must be significant changes on the interface of $\mathrm{LiFePO}_{4} / \mathrm{C}$ electrode after long term cycling.

Fig. 5 compares the discharge capacity data of $\mathrm{MCMB} \mid \mathrm{LiFePO}_{4} / \mathrm{C}$ and $\mathrm{MCMB} \mid \mathrm{LiFePO} / \mathrm{C}-$ 
PPy cells in full-cell tests at $1 \mathrm{C}$ charge/discharge rate at $55^{\circ} \mathrm{C}$. The cycling performance of the $\mathrm{MCMB} \mid \mathrm{LiFePO} / \mathrm{C}-\mathrm{PPy}$ cell is obviously improved in comparison with that of the $\mathrm{MCMB} \mid \mathrm{LiFePO} / \mathrm{C}$ cell, which is consistent with the result in half-cell test. The aforementioned results indicate that the PPy incorporation plays an important role in the remarkable improvement of the rate capability and cycling performance of $\mathrm{LiFePO}_{4} / \mathrm{C}$. It could be attributed to a synergistic effect occurred in $\mathrm{LiFePO}_{4} / \mathrm{C}$-PPy composite. Firstly, PPy in hybrid material could allow for effective electrolyte penetration into the polymer mass and form a gel-like structure, which could improve the ionic conductivity of the $\mathrm{LiFePO}_{4} / \mathrm{C}$-PPy composite and greatly reduce the electrode resistance [13]. Secondly, in the $\mathrm{LiFePO}_{4} / \mathrm{C}$-PPy composite, the excellent flexibility of PPy polymer could make the electrode more insensitive to the mechanical stresses experienced during cycling at high temperature and high rates [12]. Furthermore, PPy could also contribute to the capacity of the $\mathrm{LiFePO}_{4} / \mathrm{C}-\mathrm{PPy}$ composite [19].

To further investigate the origin of the remarkable cyclability improvement of the $\mathrm{MCMB} \mid \mathrm{LiFePO} / \mathrm{C}-\mathrm{PPy}$ cell, the cross-sectional SEM images and the corresponding EDX spectra of MCMB electrodes were measured after 200 cycles at $1 \mathrm{C}$ charge/discharge rate at 55 ${ }^{\circ} \mathrm{C}$. To prepare samples for SEM analysis, the cycled coin cells were dissembled and the MCMB anodes were rinsed with Tetrahydrofuran (THF) and dried in the glove box. EDX was carried out along the cross-section at two different locations for each sample. The results are shown in Fig. 6. In Fig. 6b, it could be found that, for the MCMB electrode of the $\mathrm{MCMB} \mid \mathrm{LiFePO}_{4} / \mathrm{C}$ cell, the Fe signal could be clearly detected throughout the cross-section of the electrode. The fact shows the dissolved $\mathrm{Fe}^{2+}$ was reduced at the surface of the MCMB electrode. However, for the MCMB electrode of the MCMB|LiFePO$/$ /C-PPy cell, the EDX spectrum (Fig. 6a) indicates that no trace of Fe metal could be detected at the carbon surface. In order to confirm the effects of the PPy coating on iron dissolution, both $\mathrm{LiFePO}_{4} / \mathrm{C}$-PPy and $\mathrm{LiFePO}_{4} / \mathrm{C}$ samples were stored in $\mathrm{LiPF}_{6}$ 
solution at $55{ }^{\circ} \mathrm{C}$ for 25 days. The iron content in the solution after 25 days storage was $10 \pm 2$ ppm for $\mathrm{LiFePO}_{4} / \mathrm{C}-\mathrm{PPy}$ and $653 \pm 30 \mathrm{ppm}$ for $\mathrm{LiFePO}_{4} / \mathrm{C}$ sample, respectively.

Above obtained results could be attributed to the fact that PPy coating could effectively protect the $\mathrm{LiFePO}_{4} / \mathrm{C}$ matrix from the corrosive solution, greatly decrease the dissolution of $\mathrm{Fe}$ in the electrolyte at elevated temperature and further suppress the reduction of Fe ions at the carbon electrode at elevated temperature, which is the main reason of the excellent cyclability of $\mathrm{LiFePO}_{4} / \mathrm{C}-\mathrm{PPy}$ against carbon electrode at elevated temperature [23-25].

\section{Conclusions}

The surface of $\mathrm{LiFePO}_{4} / \mathrm{C}$ material is modified with PPy by a simple chemical vapor deposition method. The test results demonstrate that PPy coating could not obviously improve the rate capability of $\mathrm{LiFePO}_{4} / \mathrm{C}$ material at low temperature. But the obtained $\mathrm{LiFePO}_{4} / \mathrm{C}-\mathrm{PPy}$ composite exhibits excellent rate capability at $20{ }^{\circ} \mathrm{C}$ and cycle performance at $55{ }^{\circ} \mathrm{C}$ in comparison with those of the bare $\mathrm{LiFePO}_{4} / \mathrm{C}$ material against $\mathrm{Li}$ anode. The discharge capacity of $\mathrm{LiFePO}_{4} / \mathrm{C}$-PPy composite could still remain about $80 \mathrm{mAh} \mathrm{g}^{-1}$ at $20 \mathrm{C}$ rate at $20{ }^{\circ} \mathrm{C}$ and the capacity retention of the $\mathrm{LiFePO}_{4} / \mathrm{C}$-PPy composite could still retain $82 \%$ at the 700 th cycle at 5 C charge/discharge rate at $55{ }^{\circ} \mathrm{C}$. The particular structure of $\mathrm{LiFePO}_{4} / \mathrm{C}$ particles surrounded by the PPy could improve the ionic conductivity of the $\mathrm{LiFePO}_{4} / \mathrm{C}-\mathrm{PPy}$ composite and greatly reduce the electrode resistance, which leads to a superior electrochemical performance at room temperature. Moreover, the PPy coating on $\mathrm{LiFePO}_{4} / \mathrm{C}$ could effectively decrease the dissolution of $\mathrm{Fe}$ in the $\mathrm{LiPF}_{6}$ electrolyte and consequently suppress the reduction of Fe ions at the carbon electrode at elevated temperature. Therefore, the surface modification with PPy coating is a promising approach to improve the cycle performance of $\mathrm{LiFePO}_{4} / \mathrm{C}$ at high rates and high temperature.

\section{Acknowledgements}


The authors are grateful for the financial support of this work by the National Basic Research Program of China (2007CB209705), the Natural Science Foundation of China (20773087, 21006063, 21073120), the Science and Technology Commission of Shanghai Municipality (10DZ1202702, 09DZ1203603 and 09XD1402400). 


\section{References}

[1] Padhi AK, Nanjundaswamy KS, Goodenough JB (1997) J Electrochem Soc 144:1188-1194

[2] Chen SY, Gao B, Su LH, Mi CH, Zhang XG (2009) J Solid State Electrochem 13:1361-1366

[3] Liao XZ, Ma ZF, He YS, Zhang XM, Wang L, Jiang Y (2005) J Electrochem Soc 152:A1969-A1973

[4] Kim JK, Cheruvally G, Ahn JH (2008) J Solid State Electrochem 12:799-805

[5] Chung SY, Bloking JT, Chiang YM (2002) Nat Mater 1:123-128

[6] Lu Z, Cheng H, Lo M, Chung CY (2007) Adv Funct Mater 17:3885-3895

[7] Lim S, Yoon CS, Cho J (2008) Chem Mater 20:4560-4564

[8] Muraliganth T, Murugan AV, Manthiram A (2008) J Mater Chem 18: 5661-5668

[9] Wang HB, Zeng YQ, Huang KL, Liu SQ, Chen LQ (2007) Electrochim Acta 52:5102-5107

[10]Pasquier AD, Orsini F, Gozdz AS, Tarascon JM (1999) J Power Sources 81:607-611

[11] Murugan AV, Muraliganth T, Manthiram A (2008) Electrochem Commun 10:903-906

[12]Huang YH, Goodenough JB (2008) Chem Mater 20:7237-7241

[13]Park KS, Schougaard SB, Goodenough JB (2007) Adv Mater 19:848-851

[14]Huang YH, Park KS, Goodenough JB (2006) J Electrochem Soc 153:A2282-A2286

[15]Boyano I, Blazquez JA, Meatza I, Bengoechea M, Miguel O, Grande H, Huang Y, Goodenough JB (2010) J Power Sources 195:5351-5359

[16]Wang GX, Yang L, Chen Y, Wang JZ, Bewlay S, Liu HK (2005) Electrochim Acta 50:4649-4654

[17]Fedorková A, Orináková R, Orinákb A, Taliana I, Heile A, Wiemhoerd HD, Kaniansky D, Arlinghaus HF (2010) J Power Sources 195:3907-3912

[18]Yang Y, Liao XZ, Ma ZF, Wang BF, He L, He YS (2009) Electrochem Commun 11:1277_ 1280 
[19]Wang JZ, Chou SL, Chen J, Chew SY, Wang GX, Konstantinov K, Wu J, Dou SX, Liu HK (2008) Electrochem Commun 10:1781-1784

[20]Mohammadi A, Hasan MA, Liedberg B, Lundstrom I, Salaneck WR (1986) Synth Met 14:189-197

[21]Bjorn WJ, Chen J, West K, Wallace G (2004) Macromolecules 37:5930-5935

[22]Wang BF, Qiu YL, Ni SY (2007) Solid State Ionics 178:843-847

[23]Chang HH, Wu HC, Wu NL (2008) Electrochem Commun 10:1823-1826

[24] Amine K, Liu J, Belharouak I (2005) Electrochem Commun 7:699-673

[25] Song GM, Wu Y, Liu G, Xu Q (2009) J Alloys Compd 487:214-217 
Fig. 1. TEM images of (a) $\mathrm{LiFePO}_{4} / \mathrm{C}$, and (b, c) $\mathrm{LiFePO}_{4} / \mathrm{C}-\mathrm{PPy}$.

Fig. 2. Rate capabilities of the $\mathrm{Li} \mid \mathrm{LiFePO}_{4} / \mathrm{C}$ and $\mathrm{Li} \mid \mathrm{LiFePO}_{4} / \mathrm{C}$-PPy cells at (a) $20{ }^{\circ} \mathrm{C}$ and (b) -20 ${ }^{\circ} \mathrm{C}$.

Fig. 3. Cycling performance (a) and discharge curves (b) of $\mathrm{Li}^{2} \mathrm{LiFePO}_{4} / \mathrm{C}$ and $\mathrm{Li} \mid \mathrm{LiFePO}_{4} / \mathrm{C}-\mathrm{PPy}$ cells at $5 \mathrm{C}$ charge/discharge rate at $55^{\circ} \mathrm{C}$

Fig. 4. Impedance spectra for (a) $\mathrm{Li} \mid \mathrm{LiFePO}_{4} / \mathrm{C}$ cell (b) $\mathrm{Li} \mid \mathrm{LiFePO}_{4} / \mathrm{C}-\mathrm{PPy}$ cell

Fig. 5. Cycling performance of $\mathrm{MCMB} \mid \mathrm{LiFePO}_{4} / \mathrm{C}$ and $\mathrm{MCMB} \mid \mathrm{LiFePO}_{4} / \mathrm{C}-\mathrm{PPy}$ cells at $1 \mathrm{C}$ charge/discharge rate at $55{ }^{\circ} \mathrm{C}$.

Fig. 6 Cross-sectional SEM images and EDX spectra of MCMB electrodes after 200 cycles at 1 $\mathrm{C}$ charge/discharge rate at $55{ }^{\circ} \mathrm{C}$ : (a) $\mathrm{MCMB} \mid \mathrm{LiFePO}_{4} / \mathrm{C}$-PPy (b) $\mathrm{MCMB} \mid \mathrm{LiFePO}_{4} / \mathrm{C}$. The regions in each figure index the locations where the spectra are acquired. 
Click here to download high resolution image

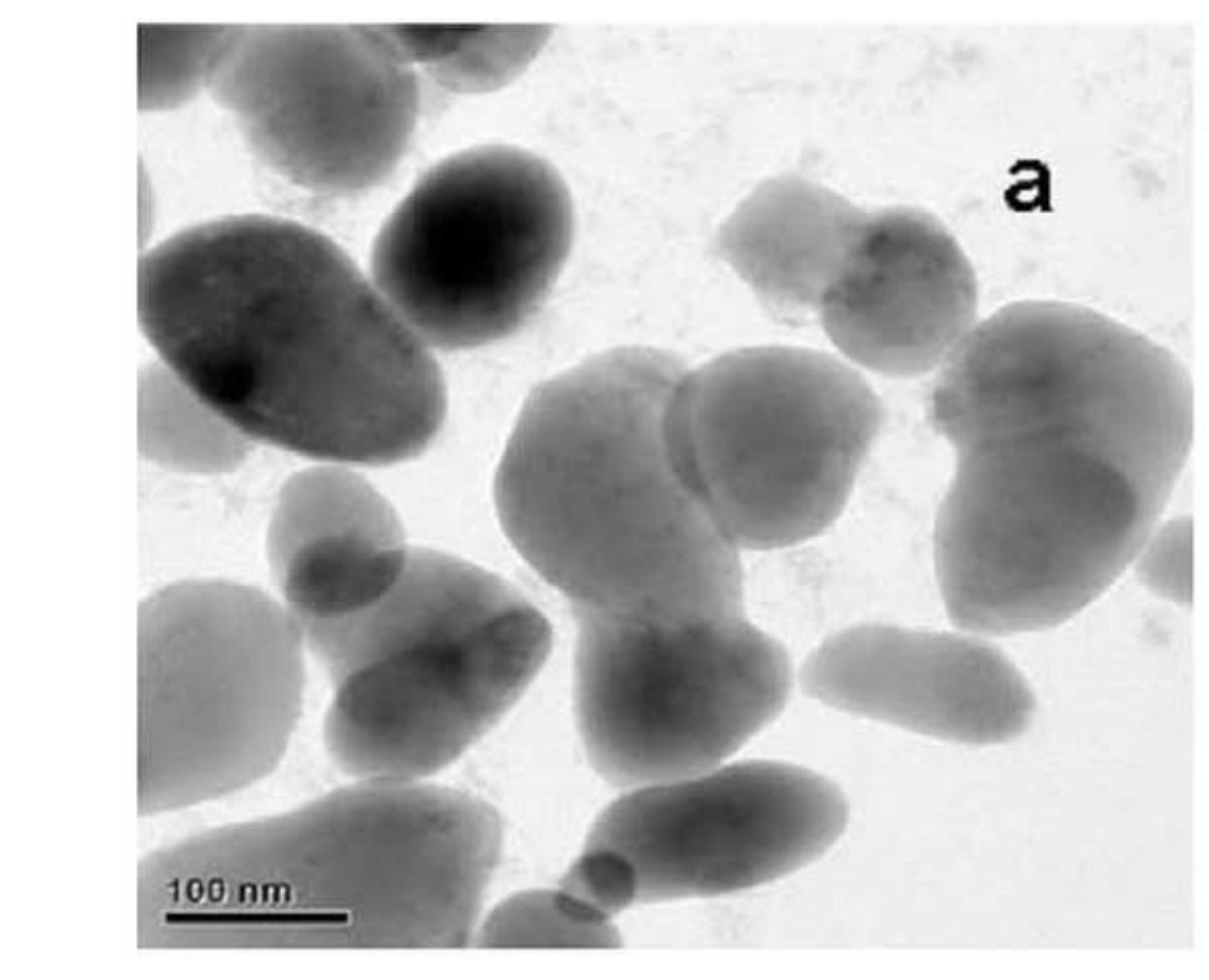

Figure1a
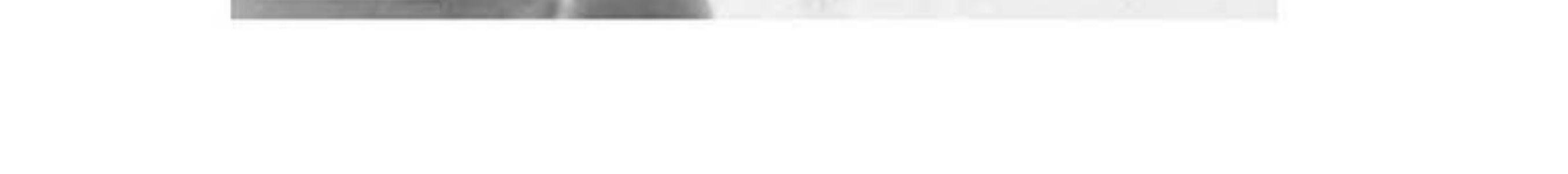


\section{Figure $1 \mathrm{~b}$}

Click here to download high resolution image

Click here to download high resolution image

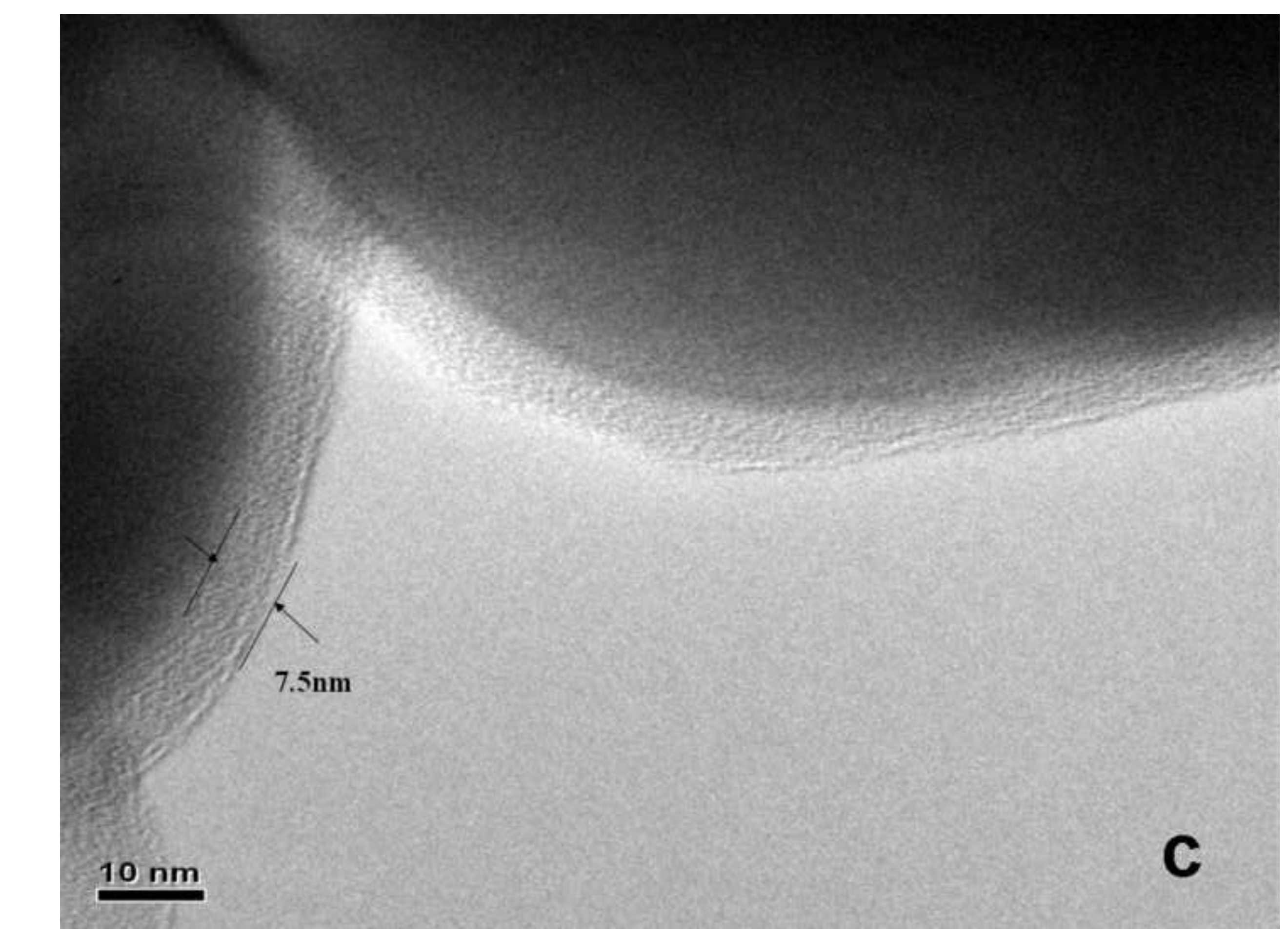

Figure1c

$10 \mathrm{~nm}$ 


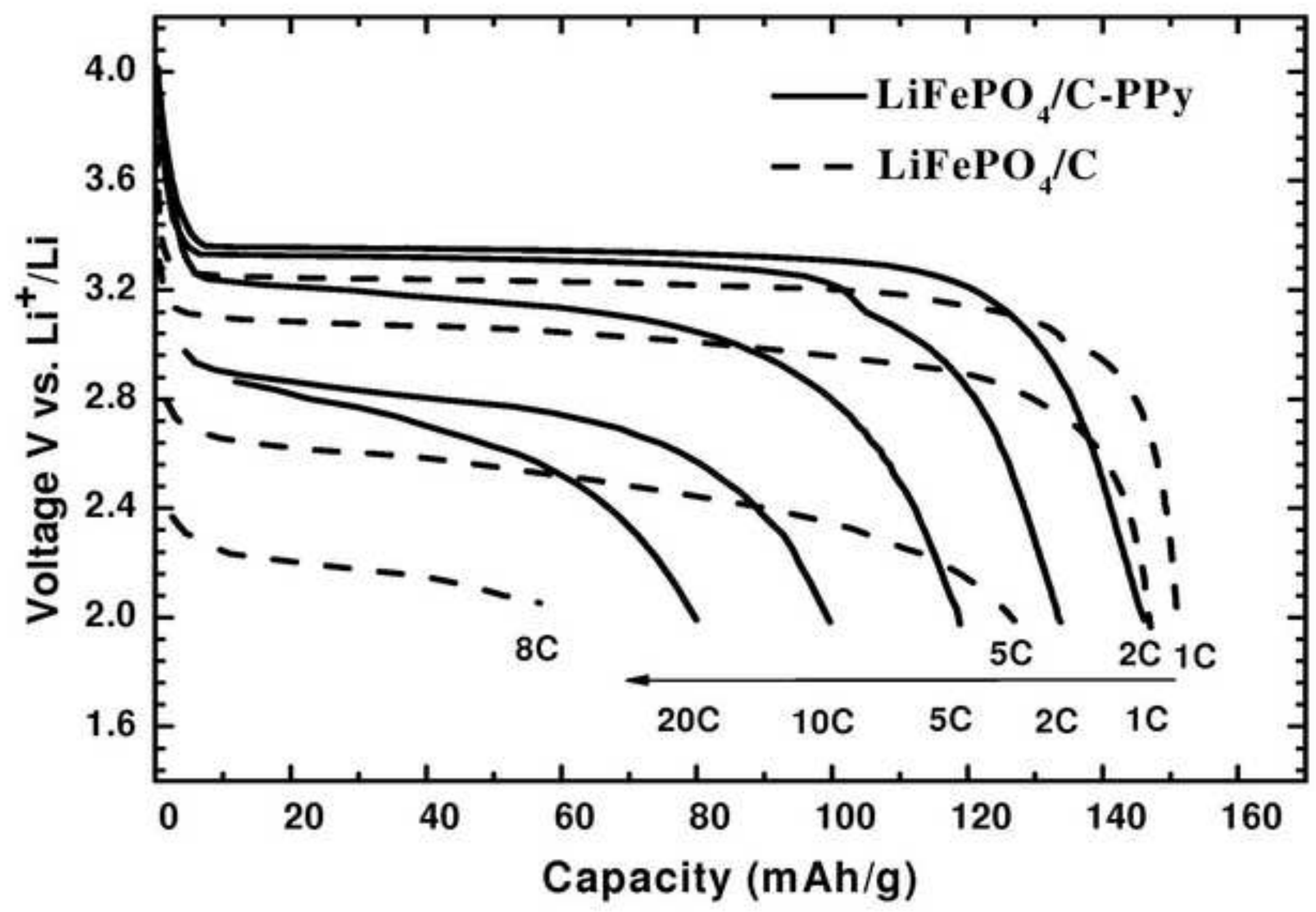




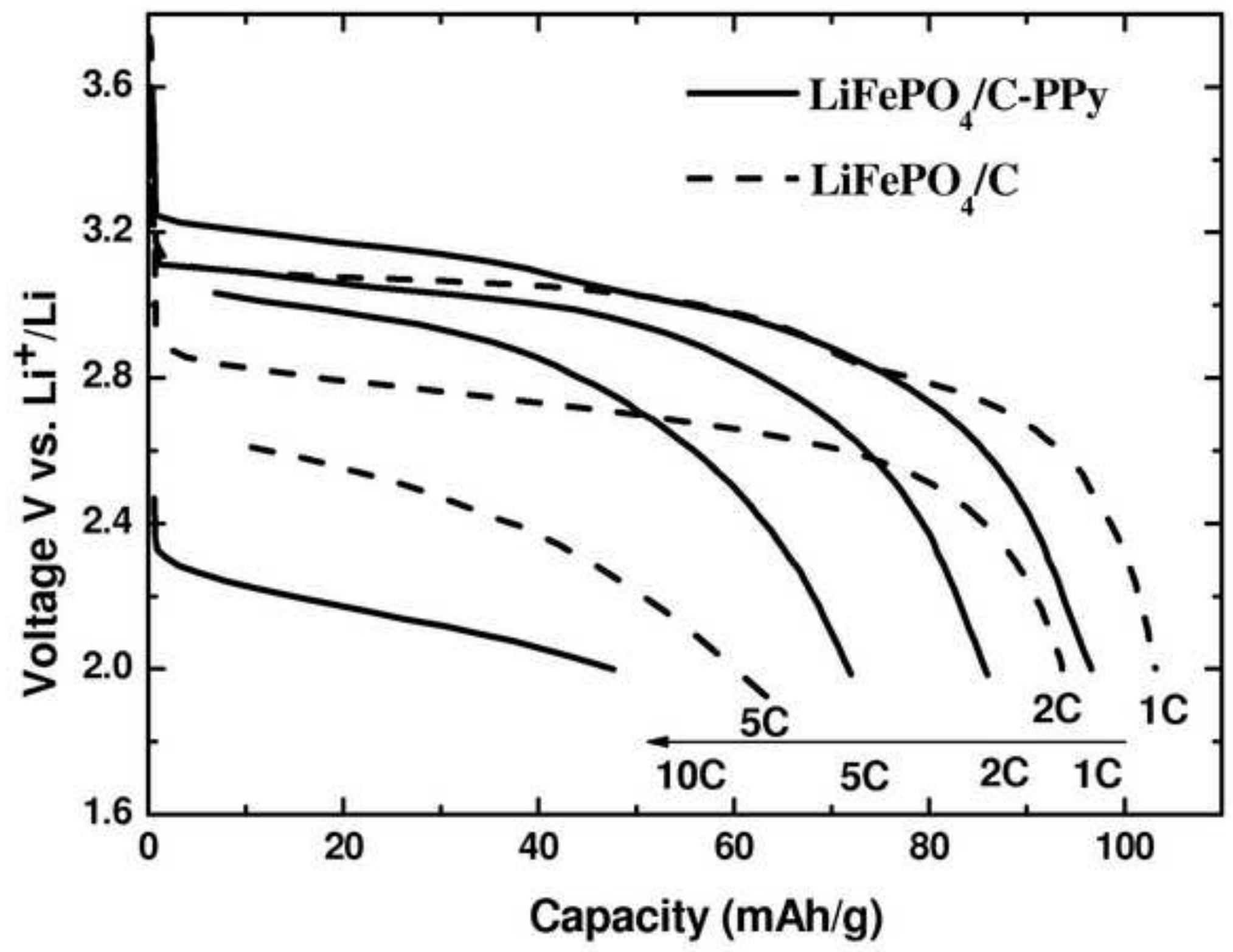









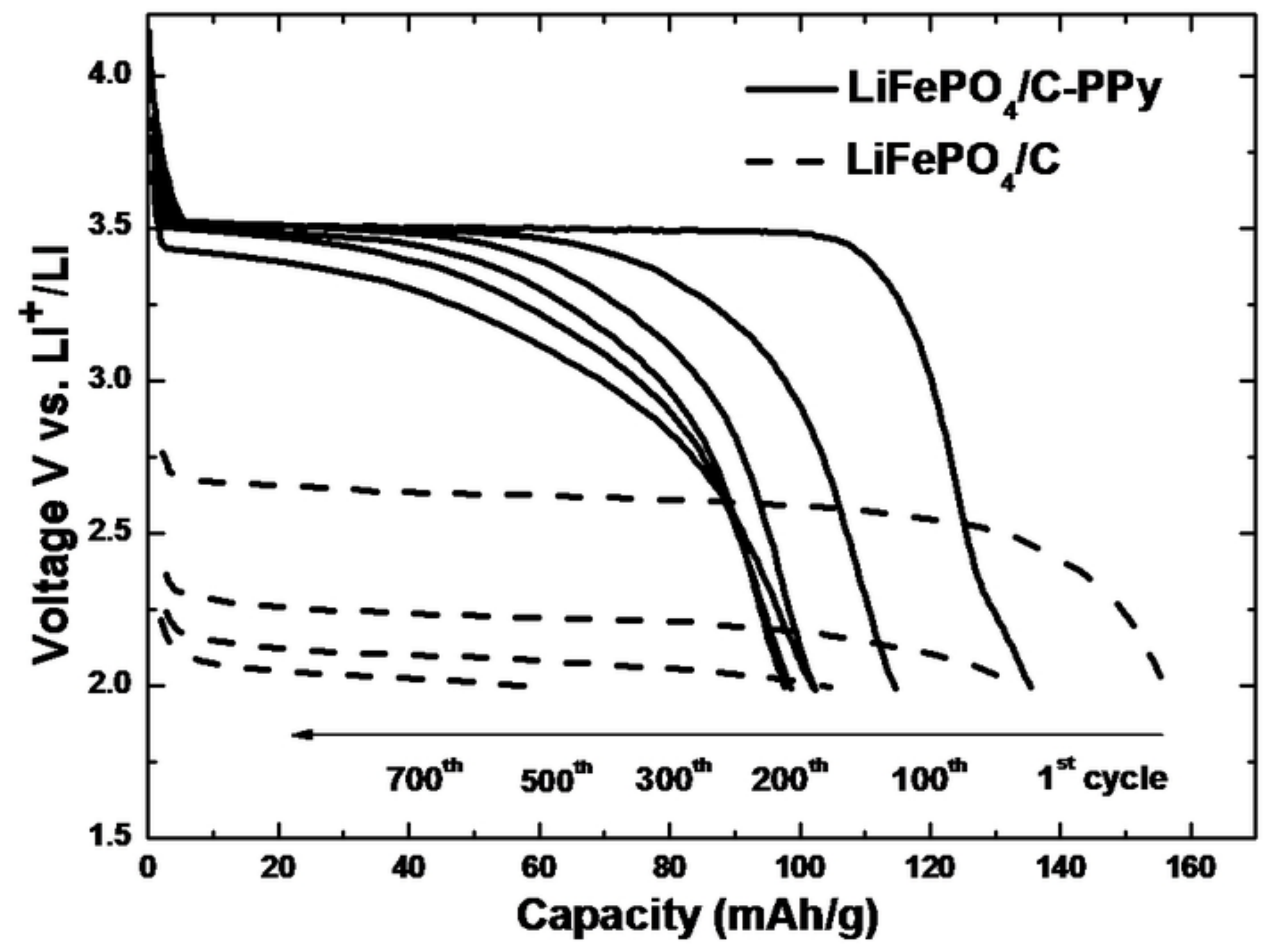




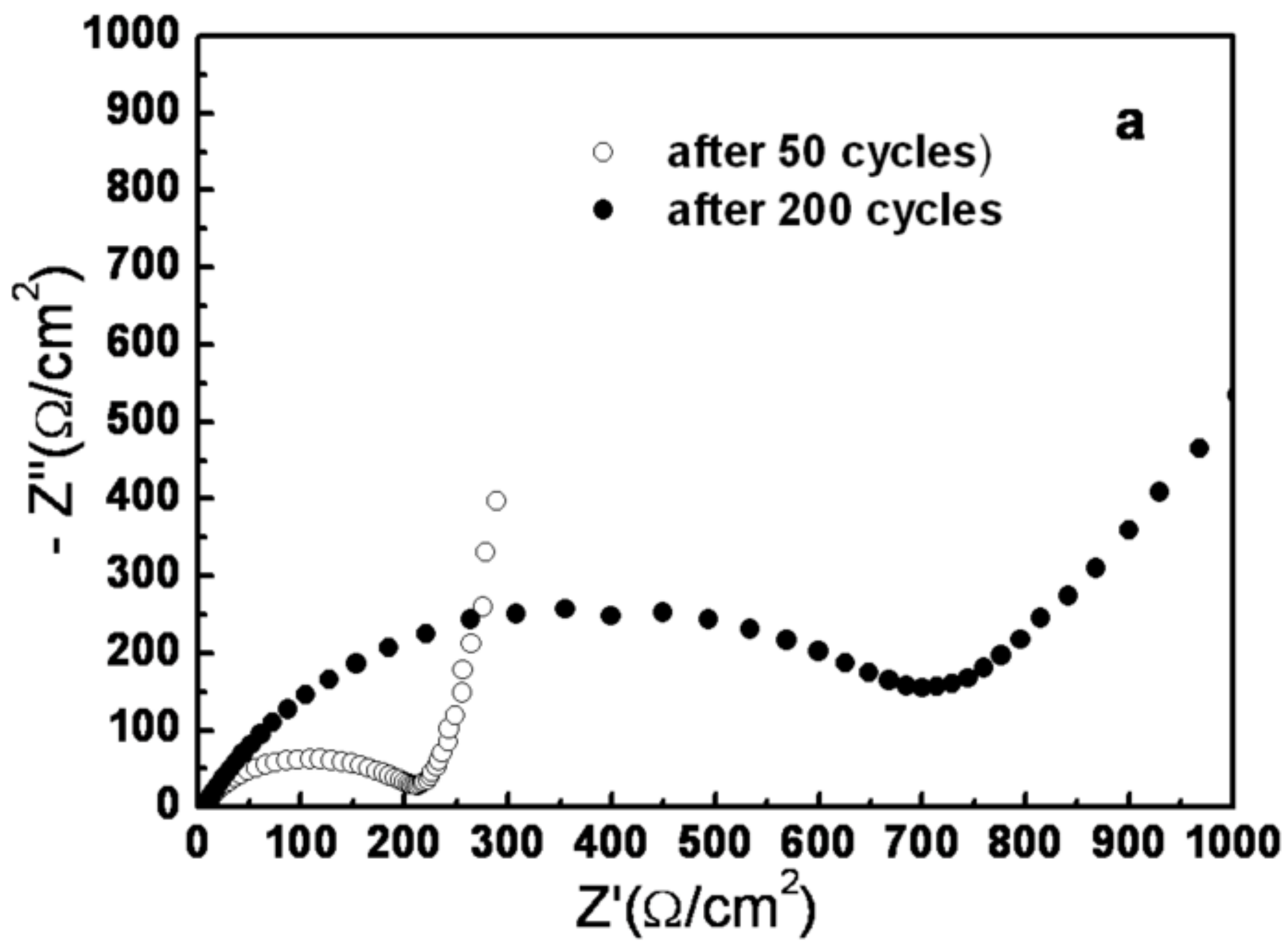









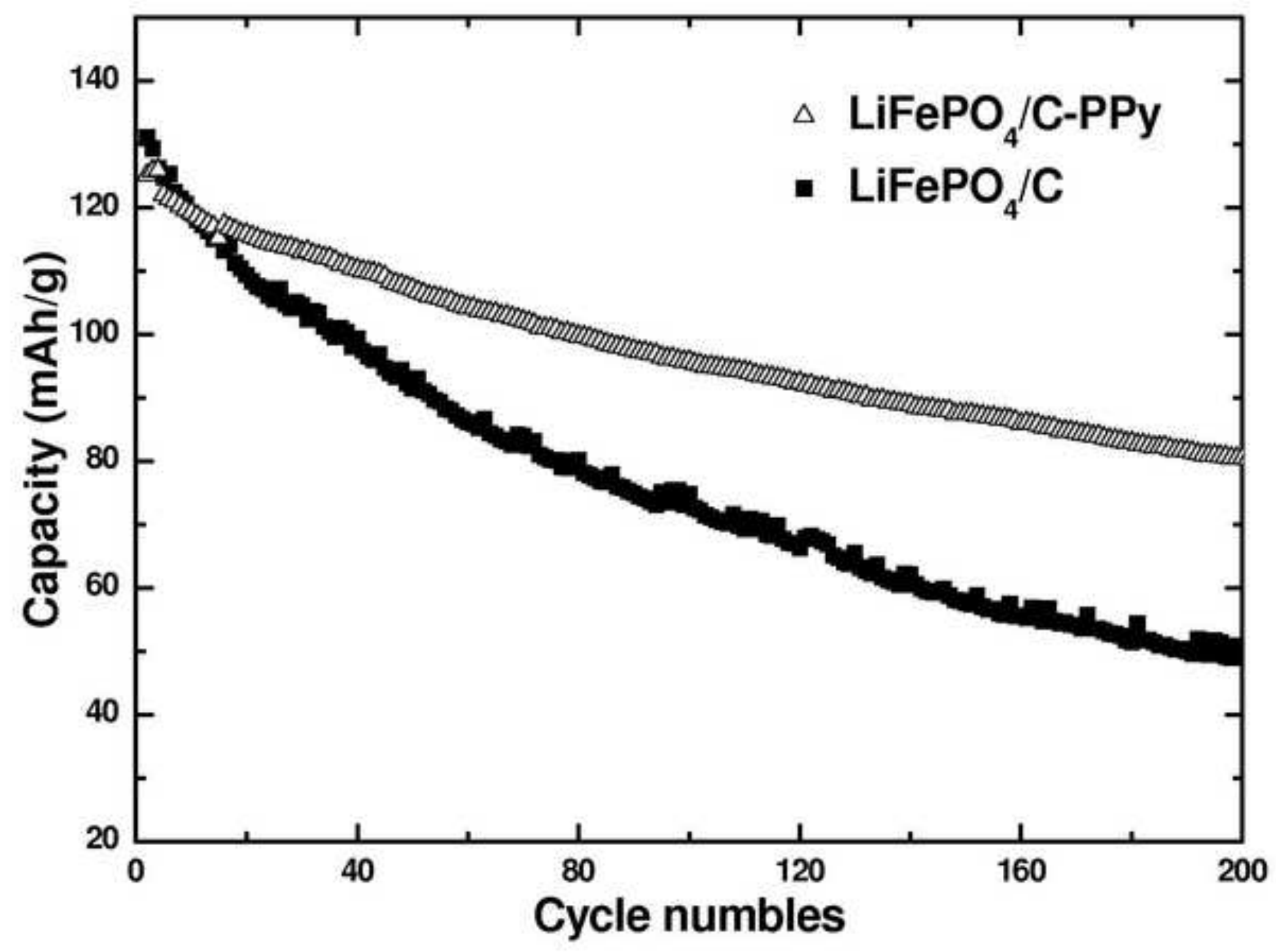


Click here to download high resolution image
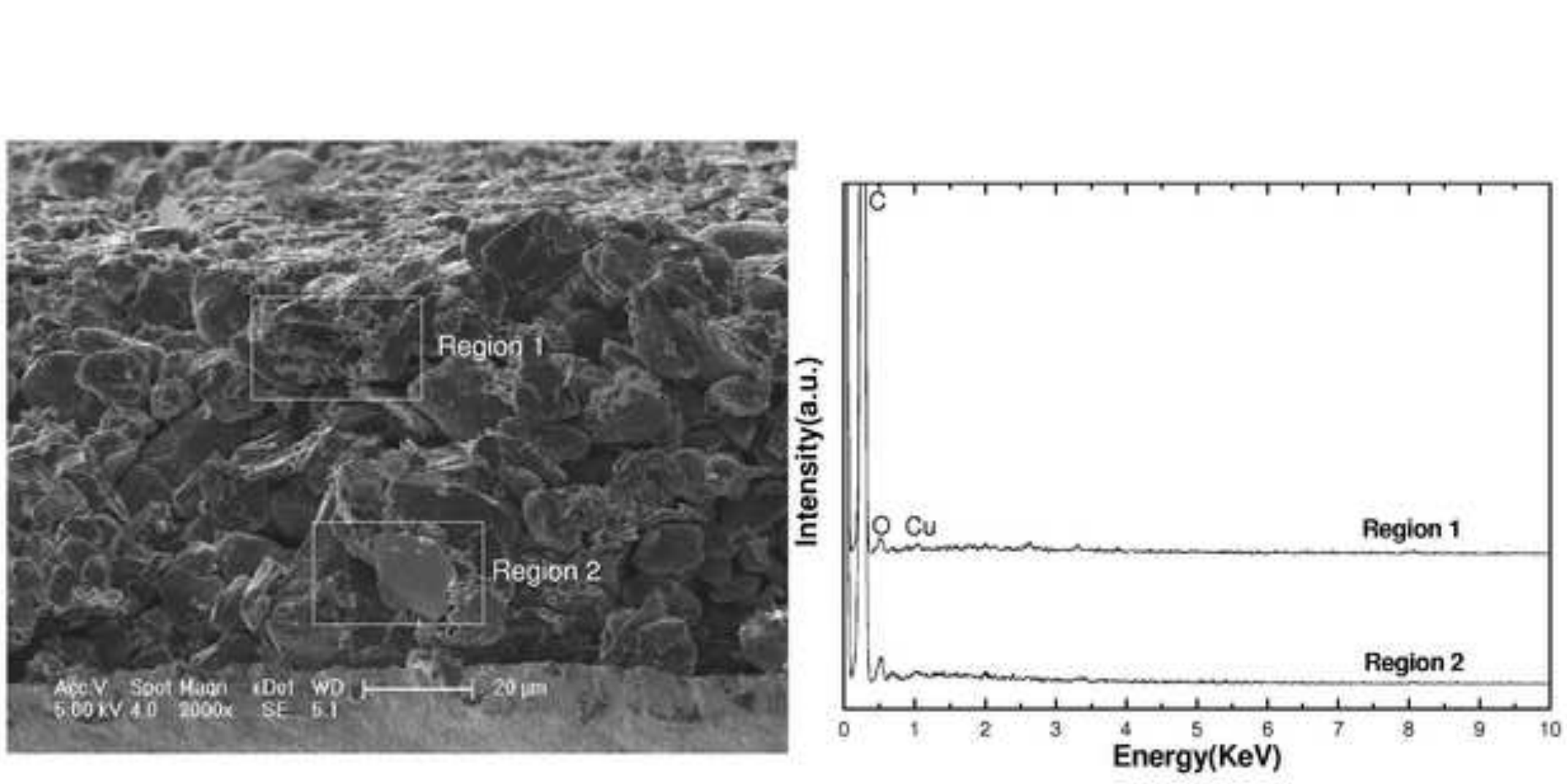

Click here to download high resc




